\title{
THE CHOICE OF ACHILLES
}

THE IDEOLOGY OF FIGURE IN THE EPIC 
This page intentionally left blank 


\section{THE CHOICE OF ACHILLES}

THE IDEOLOGY OF FIGURE IN THE EPIC

Susanne Lindgren Wofford 
Stanford University Press, Stanford, California

(C) 1992 by the Board of Trustees of the Leland Stanford Junior University

Printed in the United States of America

Published with the assistance of the Frederick W. Hilles Publications Fund at Yale University

CIP data appear at the end of the book 
For Jacques 
This page intentionally left blank 